\title{
Effect of Cantileverd Bar Length on Strain Around Two and Four-Implants Supporting A Mandibular Over-Denture
}

\author{
Mohamed Sherine El Attar ${ }^{1}$, Faten Salah El Din ${ }^{2}$, Jailan Salem ${ }^{3}$ \\ ${ }^{1}$ Professor of Prosthodontics, Alexandria University Faculty of Dentistry, Alex, Egypt \\ ${ }^{2}$ Professor of Prosthodontics, Alexandria University Faculty of Dentistry, Alex, Egypt \\ ${ }^{3}$ BDS, MS, Alexandria University, Faculty of Dentistry, Alex, Egypt
}

\begin{abstract}
Statement of problem: There is little information as to how the cantilevered bar length affect the strain around two and four implants supporting a mandibular over denture Purpose: measure the effect of cantilevered bar length on strain produced around twoimplant and four-implant supporting a mandibular over denture, and evaluating the amount of stress reaching the supporting structures. Materials and methods: Two root-form implants were placed bilaterally in the canine region of an edentulous acrylic mandibular model (group A). Also four root-form implants were placed in the canine \& bicuspid region of another edentulous acrylic mandibular model (group B). The implants on each model were connected with a resilient bar/clip attachment with the following lengths of cantilevered bar length: $11 \mathrm{~mm}, 9 \mathrm{~mm}$ and $7 \mathrm{~mm}$.Four linear strain gauges were bonded to the acrylic resin at the mesial \& distal surface of each implant. Each gauge was wired separately into a 1/4 Wheatstone bridge of a multichannel digital bridge amplifier. Strains were measured on each model. Strain measurements were performed under central loading using a loading device. Results: when using two or four implants, the $11 \mathrm{~mm}$ cantilevered bar length generated the highest peri-implant strain values, while the $7 \mathrm{~mm}$ cantilever length recorded the lowest under central loading conditions. A positive correlation between the cantilever length and the periimplant strain was found. The same effect was found on the supporting structures. Conclusion: The 7mm cantilevered bar with clips placed on the cantilevers was recommended when 2 or 4 implants were used to support mandibular over dentures as it demonstrated the lowest magnitude of strains with no significant differences between peri-implant sites
\end{abstract}

Keywords: Cantilever, bar, strain, implant, overdenture.

\section{Introduction}

The benefits of implant-retained/ supported mandibular implant overdenture (IOD) treatment relative to conventional mandibular denture treatment have been well documented [1-9]. Half of all conventional mandibular dentures demonstrate problems with prosthesis stability and retention, with retention being the single most important deficiency reported [10].

Feine et al [11] and Thomason et al [12] stated that for the edentulous mandible, a 2-implant overdenture treatment should be the standard of care relative to conventional denture treatment

Enhanced prosthesis retention and stability have been identified as perhaps the most important factors for producing more favorable mandibular IOD treatment outcome and improved patient satisfaction [2,10,13] Mandibular IOD prosthesis retention, stability, and support are provided by both the mucosa and implants. As increasing numbers of implants are used, it is possible they will assume a greater role with treatment outcome, particularly involving prosthesis support [14].However, more implants may not translate to improved prosthesis retention and/or stability, and subsequent treatment outcome may be relatively unaltered,[14] other than a slight increased risk from additional treatment and added expense. Zarb and Schmitt[15] and Visser et al [16] indicatedthat successful IOD treatment outcome can be achieved regardless of the number of implants used, but this concept remains controversial[14] Two implants have been considered the minimum necessary for mandibular IOD treatment $[1,15]$ and can be used either with independent, unsplinted attachments or splinted together using a cast metal bar and bar-clip attachment[17] Four implantssplinted with 3 interconnecting bar and bar-clip attachments is another treatment alternative. With a lack of consensus regarding the number of implants necessary for mandibular implant overdenture treatment, the best choice of an attachment mechanism between the implants and denture base also remains controversial. The design of attachments should provide equal implant-tissue support and optimum force distribution around the implants to allow bone loading within physiologic levels $[18,19]$. Consequently stress breaking retention mechanism as egg-shaped Dolder bar or ball anchors may be selected [20] Implants splinted together with bars may decrease the risk of overload to each implant as a result of a greater surface area, load sharing between implants and improved biomechanical distribution $[21,22]$. The bar's ability to minimize the potential for micromotion at the bone-implant interface may help successful osseointegration of immediately loaded implants[23,24].

Wismeijer et al [26] studied 110 mandibular IOD patients, who received either 2 implants with a ball attachment, 2 implants with an interconnecting bar, or 4 implants splinted with 3 bars. Treatment outcome was measured using patient questionnaires. Nearly all subjects were satisfied with treatment after 16 months, and no statistical difference was found among the 3 treatment strategies. The authors concluded that the 2 -implant ball attachment treatment was a

\section{Volume 4 Issue 12, December 2015}




\section{International Journal of Science and Research (IJSR) \\ ISSN (Online): 2319-7064}

Index Copernicus Value (2013): 6.14 | Impact Factor (2014): 5.611

good choice, but the need for additional clinical trials was emphasized

Several authors have emphasized the importance of designing a single bar parallel with the hinge axis to encourage torsionfree load transmission to implants[26,27]. However this design showed continued bone resorption in the edentulous regions due to overdenture rotation during function [28]. Other authors reported the use of short distal cantilevers added to the bar which connects 2 implants[3,29,30]. Such prosthesis design increases prosthesis rigidity, decreases overdenture rotation during function, enhances prosthesis stability and retention, and provides a more conservative surgical and economic treatment. The increased prosthesis rigidity creates a stable occlusal plane, reduces loading of denture-bearing areas[31], and decreases posterior mandibular ridge resorption [28]. Moreover, it improves chewing [32], decreases the incidence of prosthodontic maintenance [33], reduces soft tissue irritation, protects mental nerve, and diminishes problems of high muscle attachment and prominent mylohyoid ridge [20]. The supporting area of bars with distal cantilevers also was found to be greater than straight or slightly bent bars without distal cantilevers [19].

Several in-vitro methods have been used to evaluate the biomechanical load on implants such as photoelastic, finite element, and strain-gauge stress analysis [34]. Electrical strain gauges have been used extensively for quantitative analysis of the stresses around implants supporting a mandibular overdenture [18,21,35-38]. When the load is applied, strains in the surface of the specimen under examination are transmitted to the wire filament of the gauges via a paper backing cemented onto the surface[38].

Misch [39] stated that when two implants are connected together with a cantilevered bar, the prosthesis has less movement and moment forces are increased on implants. Increased tensile strain values at the bone/implant interface arenot desired, since they may cause bone loss through the induction of bone microdamage [40-42]. In contrast, in vivo studies showed a minimal influence of distal bar cantilevers on strains around 2 implants supporting mandibular overdentures[30]. Such distal cantilevers were also found to have a little or no influence on the stability of periimplant clinical parameters or implant survival [19]. However these invivo studies were insufficient to derive data concerning the biomechanical environment of bone tissue around implants [21].

Accordingly, the aim of this study was to evaluate the effect of cantilevered bar length on strain around 2 implants and four implants supporting a mandibular overdenture by means of strain gauge analysis.Also to evaluate the magnitude of the stresses reaching the supporting structures.The null hypothesis was that there will be a difference between the tested cantilevered bar lengths.

\section{Material and Methods}

This study had been done in the Removable Prosthodontic and dental biomaterial Departments, Faculty of Dentistry, Alexandria University.
One maxillary and two readymade completely edentulous acrylic resin models were used. A layer of mucosa simulating material (Mollosil) was placed on each heat cured acrylic resin mandibular model.

- A stone model was duplicated from each heat cure acrylic resin model using addition silicon duplicating material each stone model was used for construction of conventional acrylic resin complete denture.

- One maxillary and two Mandibular record blocks were constructed on the duplicated stone models then waxed up and mounted on mean value articulator. Both the two mandibular record blocks were mounted simultaneously against the same maxillary record block to get the same configuration of both the mandibular complete dentures.

- Semi-anatomic acrylic resin teeth (with the same size and morphology for both dentures) were selected and arranged.

- The two mandibular trial dentures were then flasked,packed with acrylic resin, cured, finished,and polished following the conventional steps to get two acrylic mandibular complete denture.

- The two readymademandibular completely edentulous acrylic models were classified as group A receiving two implants and the other model as group B receiving four models. On both group A (model with two implants) and group $\mathrm{B}$ (model with four implants) the mucosa simulating material was removed and the root form implants were placed.

- For Group A: Two holes (length:13mm long, width: $3.5 \mathrm{~mm}$ in diameter) were drilled bilaterally over the edentulous ridge of the study acrylic model $22 \mathrm{~mm}$ apart (each was $11 \mathrm{~mm}$ from the midline) simulating the inter-canine distance.

- For Group B: Four holes (length:13mm long, width: $3.5 \mathrm{~mm}$ in diameter) were drilled over the edentulous ridge of the study acrylic model, two of the holes were drilled $22 \mathrm{~mm}$ apart (each was $11 \mathrm{~mm}$ from the midline) simulating the intercanine distance, the other two were drilled at the premolar region bilaterally.

- The root-form implants( CT-5113,C-TECH Century implant technologies Via Santa Margherita al Colle n.18-40136, Bologna- ITALY) (3.5 mm in diameter, $13 \mathrm{~mm}$ long) were inserted in the drilled holes for both group A and B models,.

- For both group A and group B, the mucosa simulating material was returned again then it was punched out over each implant to attach the readymade abutment.

- On each implant,a castablereadymade plastic multi-unit abutment (C-TECH Century implant technologies Via Santa Margherita al Colle n.18-40136, Bologna- ITALY) was placed on each implant and the multi -unit internal screw was tightened.

- For group A : one readymade plastic Bar segment was luted between the castable abutments using sticky wax, leaving $2 \mathrm{~mm}$ clearance space between the bar and the ridge. Another two plastic bars were designed and fixed with bilateral distal cantilevers ( $11 \mathrm{~mm}$ in length) for model A. (Fig. 1) 


\section{International Journal of Science and Research (IJSR) \\ ISSN (Online): 2319-7064}

Index Copernicus Value (2013): 6.14 | Impact Factor (2014): 5.611

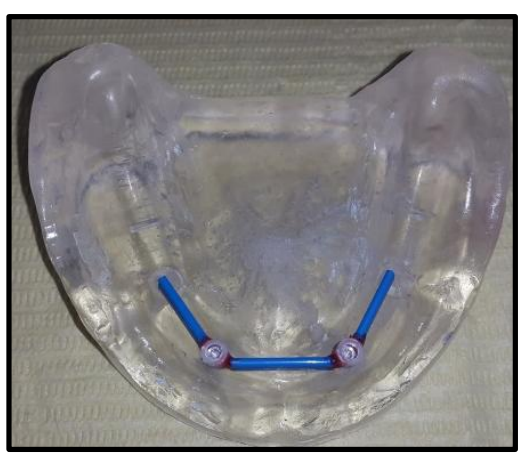

Figure 1: Bars luted for group A.

- For group B : three bar segments were fixed between the readymadecastable abutments using sticky wax, leaving 2 $\mathrm{mm}$ clearance space between the bar and the ridge.Another two bars were designed and fixed with bilateral distal cantilevers (11 mm in length).(Fig.2)

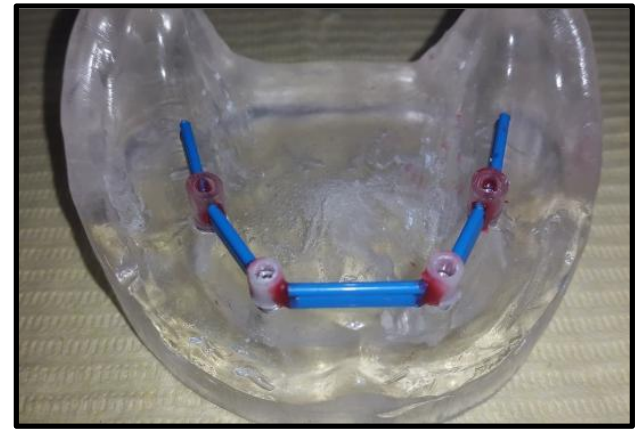

Figure 2: Bars luted for group B.

- For both models, all the plastic abutments and plastic bar segments were removed from the model, sprued, invested, casted, finished and polished according to the manufacturer's instructions.

- After proceesing, processed abutments and bar segments were returned back on both models and fixed using a tightening screw. Resilient retentive clips attachments were adapted over each bar segment attachment

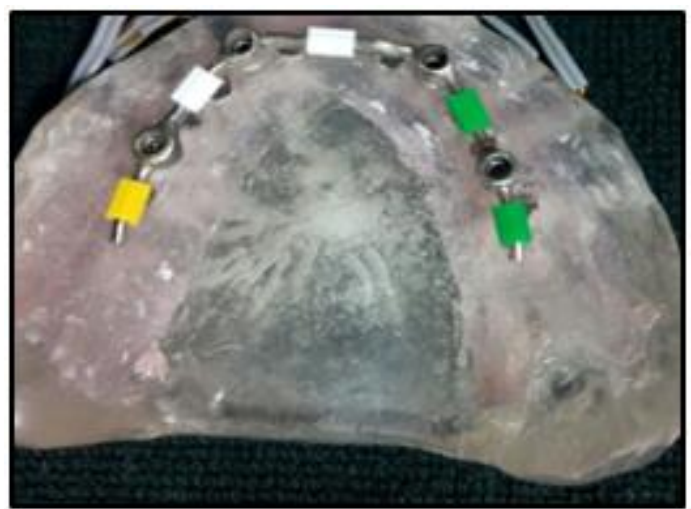

Figure 3: Ot-clips attachment were adapted over each bar

- The previously constructed complete dentures were modified to be used as implant supported overdenture as follows:

- For both groups, holes were drilled at the inner surface of the complete denture facing each implant abutment, an acrylic layer was removed from the inner surface of the denture opposite to each clip attachment.

- A mix of self-cure acrylic resin material was added to the inner surface of the denture, and then the denture was adapted over the ridge to pick up the retentive bar's clip.

- The bar was initially casted with 2 distal cantilevers of 11 $\mathrm{mm}$ length, then the cantilevers were shortened $2 \mathrm{~mm}$ in two occasions (length becomes $9 \mathrm{~mm}$ and $7 \mathrm{~mm}$ ).

- In each time of length modification, the retentive clips of the cantilevers were removed from the denture and new clips were attached to the overdenture.

- Since it is not feasible to measure the moments generated at an implant directly, it was assumed that strain measured on the resin around the implants could be representative of stress that is introduced to the bone.

- The stress distribution was analyzed and recorded at the peri implant tissue and at the alveolar ridge around the cantilevered bars using strain gauges as follows:

\section{A. Strain Gauge Fixation}

- Acrylic resin was removed around mesial and distal surface of each implant leaving $1 \mathrm{~mm}$ of resin intact.

- Two linear strain gauges were bonded to the acrylic resin model at mesial (M) and distal (D) surface of each implant using a Cyanoacrylate adhesive to measure the axial strain around the implants(peri implant tissue).

- The long axes of each gauge was oriented parallel to the long axes of each implant. The fine lead wires were brought through channels prepared in the acrylic resin model.

- Also, for both groups : eight strain gauges were connected to the fitting surface of the implant overdentures (where four gauges were connected to the buccal and lingual flanges at right side) and four gauges to the left side to measure the amount of strain at the over denture supporting structures opposite the cantilevered bars. (Fig.3)

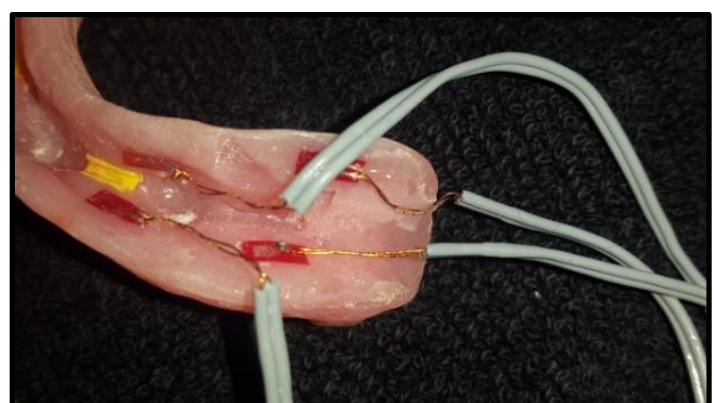

Figure 4: Strain gauges connected to the fitting surface of the implant overdenture

\section{B. Strain Gauge Calibration}

Before strain measurements, a calibration experiment to the gauges was made to assess the repeatability of force measurements and the linearity of the gauges. A cyclic load ranging from 10 to $60 \mathrm{~N}$ was applied 6 times in a 10-Nsteps on the occlusal surface of mandibular implant supported over- denture using a loading device to age the gauges. The purpose of the "aging" was to minimize hysteresis, a lagging or retardation of the effect when forces acting upon a body were changed.

\section{Volume 4 Issue 12, December 2015}




\section{International Journal of Science and Research (IJSR) \\ ISSN (Online): 2319-7064}

Index Copernicus Value (2013): 6.14 | Impact Factor (2014): 5.611

\section{Strain Gauge Measurements}

- Strains were measured for group A with cantilever bar lengths: $11 \mathrm{~mm}$ (subgroup A1), 9mm (subgroup A2), and $7 \mathrm{~mm}$ (subgroup A3).

- Strains were also measured for group B with cantilever bar lengths: $11 \mathrm{~mm}$ (subgroup B1), 9mm (subgroup B2), and $7 \mathrm{~mm}$ (subgroup B3).

\section{Loading Procedures}

- For each model (group A and group B): A metal bar was positioned between the right and left denture bases at the level of the occlusal plane over the region of the mesial cusps of each first molar.

- Each model was attached to a loading apparatus with the occlusal plane of the overdenture in a horizontal position. A moderate level of biting force (60 Newtons regarded as maximal occlusal force) was applied to the center of the metal bar using the loading device (LLOYD LRX, LLOYD instruments Ltd., Fareham, Hampshire, UK).

- The right and left strain values at mesial and distal periimplant sites under central loading were combined for each applied load also opposite the buccal and lingual flanges at right and left sides of the implant overdenture.

- All measurements were repeated 6 times allowing at least 5 minutes for recovery, and the mean of recorded micro strain was subjected to statistical analysis.

- For both models the same steps were repeated.

The resulting data were fed to the computer and analyzed using IBM SPSS software package version 20.0 .Quantitative data were described in Newton as range (minimum and maximum) mean, standard deviation and median. The distributions of quantitative variables were tested for normality using Kolmogorov-Smirnov test, Shapiro-Wilk test and D'Agstino test and revealed a normally distributed data. Accordingly, Comparison between two independent data was done using independent t-test; Comparison between multiple data was done using ANOVA with repeated measures and Post Hoc test was assessed using Tukey LSD. Significance test results were quoted as twotailed probabilities. Significance of the obtained results was judged at the $5 \%$ level. A p-value of less than 0.05 was considered statistically significant.

\section{Results}

The strain measured at the periimplant sites in group A was in its highest value when $11 \mathrm{~mm}$ cantilever bar length was used $(24.58 \pm 5.17)$ and the lowest value when $7 \mathrm{~mm}$ cantilever length was used $(20.71 \pm 3.86)$ where $\mathrm{p}<0.001^{*}$.

Also, the strain measured at the periimplant sites in group B was in its highest value when $11 \mathrm{~mm}$ cantilever bar length was used $(22.88 \pm 5.39)$ and the lowest value when $7 \mathrm{~mm}$ cantilever length was used $(19.0 \pm 8.10)$ where $\mathrm{p}=0.021^{*}$.

There was no statistical significance values between the two groups when using the three different cantilevered lengths were $\mathrm{p}=0.269$ when using the $11 \mathrm{~mm}, \mathrm{p}=0.494$ when using 9 $\mathrm{mm}$ and $\mathrm{p}=0.358$ when using $7 \mathrm{~mm}$ cantilever bar
lengths(Table 1).

Table 1: Comparison of the strain values at the periimplant sites between group A and group B.

\begin{tabular}{|c|c|c|c|c|}
\hline & $\begin{array}{l}\text { Group A } \\
(n=24)\end{array}$ & $\begin{array}{l}\text { Group B } \\
(n=24)\end{array}$ & $T$ & $P$ \\
\hline \multicolumn{5}{|l|}{$7 \mathrm{~mm}$} \\
\hline Min. - Max. & $13.0-28.0$ & $10.0-34.0$ & \multirow{3}{*}{0.933} & \multirow{3}{*}{0.358} \\
\hline Mean \pm SD. & $20.71 \pm 3.86$ & $19.0 \pm 8.10$ & & \\
\hline Median & 21.0 & 15.0 & & \\
\hline \multicolumn{5}{|l|}{$9 \mathrm{~mm}$} \\
\hline Min. - Max. & $15.0-30.0$ & $6.0-36.0$ & \multirow{3}{*}{0.692} & \multirow{3}{*}{0.494} \\
\hline Mean \pm SD. & $21.42 \pm 4.53$ & $20.0 \pm 8.95$ & & \\
\hline Median & 20.50 & 18.5 & & \\
\hline \multicolumn{5}{|l|}{$11 \mathrm{~mm}$} \\
\hline Min. - Max. & $16.0-34.0$ & $15.0-35.0$ & \multirow{3}{*}{1.120} & \multirow{3}{*}{0.269} \\
\hline Mean \pm SD. & $24.58 \pm 5.17$ & $22.88 \pm 5.39$ & & \\
\hline Median & 25.0 & 22.0 & & \\
\hline $\mathrm{F}$ & $22.783^{*}$ & $4.203^{*}$ & & \\
\hline $\mathrm{P}$ & $<0.001^{*}$ & $0.021^{*}$ & & \\
\hline
\end{tabular}

t: Student t-test

*: Statistically significant at $\mathrm{p} \leq 0.05$

The strain measured at the distal supporting structures in group A was in its highest value when $11 \mathrm{~mm}$ cantilever bar length was used $(41.79 \pm 26.98$ and the lowest value when 7 $\mathrm{mm}$ cantilever length was used $(31.98 \pm 15.16)$.

Also, the strain measured at the distal supporting structures in group B was in its highest value when $9 \mathrm{~mm}$ cantilever bar length was used $(54.79 \pm 17.35)$ and the lowest value when 7 $\mathrm{mm}$ cantilever length was used $(38.92 \pm 11.65)$.

There was no statistical significance difference between the two groups when using $11 \mathrm{~mm}$ cantilever bar length where $\mathrm{p}=0.787$, while there was a statistical significance difference when using $9 \mathrm{~mm}$ and $7 \mathrm{~mm}$ where $\mathrm{p}<0.001$ and 0.014 respectively with increased strain value in group B by use of four implants supported overdenture(Table 2).

Table 2: Comparison of the strain values at the supporting structures between group A and group B

\begin{tabular}{|c|c|c|c|c|}
\hline & Group A & Group B & $t$ & $p$ \\
\hline \multicolumn{5}{|l|}{$7 \mathrm{~mm}$} \\
\hline Min. - Max. & $5.0-90.0$ & $15.0-70.0$ & \multirow{3}{*}{$2.514^{*}$} & \multirow{3}{*}{$0.014^{*}$} \\
\hline Mean \pm SD. & $31.98 \pm 15.16$ & $38.92 \pm 11.65$ & & \\
\hline Median & 30.0 & \begin{tabular}{|l|}
40.0 \\
\end{tabular} & & \\
\hline \multicolumn{5}{|l|}{$9 \mathrm{~mm}$} \\
\hline Min. - Max. & $12.0-90.0$ & $15.0-90.0$ & \multirow{3}{*}{$4.187^{*}$} & \multirow{3}{*}{$<0.001^{*}$} \\
\hline Mean \pm SD. & $37.31 \pm 23.14$ & $54.79 \pm 17.35$ & & \\
\hline Median & 28.50 & \begin{tabular}{|l|}
55.0 \\
\end{tabular} & & \\
\hline \multicolumn{5}{|l|}{$11 \mathrm{~mm}$} \\
\hline Min. - Max. & $5.0-90.0$ & $15.0-85.0$ & \multirow{3}{*}{0.272} & \multirow{3}{*}{0.787} \\
\hline Mean \pm SD. & $41.79 \pm 26.98$ & $43.04 \pm 16.98$ & & \\
\hline Median & 31.0 & 40.0 & & \\
\hline
\end{tabular}

$\mathrm{t}$ : Student t-test

$*$ : Statistically significant at $\mathrm{p} \leq 0.05$

\section{Discussion}

Our study was carried out in vitro as it seemed beneficial in providing valid comparative data excluding the effect of variation among individuals. In addition, variation of oral hygiene, strength of masticatory muscles, age and sex are 


\section{International Journal of Science and Research (IJSR) \\ ISSN (Online): 2319-7064}

Index Copernicus Value (2013): 6.14 | Impact Factor (2014): 5.611

factors representing further difficulties to reach definiteresult in the clinical evaluation. Accordingly, this study was carried out in-vitro to omit human variation and to produce more realistic results.

Two implants design have been used in this study as Two implants have been considered the minimum necessary for mandibular implant overdenture treatment[2][9] and can be used either with independent unsplinted attachments or splinted together using a cast metal bar and a bar-clip attachment[10].

Comparative prospective studies validate the benefit of two or four implants in the edentulous mandible[11][12]therefore, four implants have been used in this study as four implants splinted with 3 interconnecting bar and bar-clip attachments is another treatment alternative for mandibular archs.

Implants were placed bilaterally at the anterior mandible (especially the inter-canine distance).The anterior area was chosen as many studies concluded that this area showed high success rates of implants when loaded with over dentures[14].

The implants were placed at $22 \mathrm{~mm}$ distance apart because this distance was used to resemble the distance between the two natural canines[16].

Despite there are many techniques for stress analysis, in the current study one technique of the most commonly used techniques for measuring and analyzing stress distribution in dental field were used; strain gauge analysis.

The use of a strain gauge technique for measuring a strain value is a very sensitive procedure that involves multiple components. A simple error can be enough to alter the results. In addition, the strain gauge only measures the surface where it has been attached; therefore, the recorded strain from the prosthesis can be dependent on location of bonded strain gauge [20].

Since it is almost impossible to reproduce chewing pattern by in vitro experiments, a moderate level of biting force (60 Newtons regarded as maximal occlusal force) was delivered to the center of the metal bar using the loading device [22[.

In the current study, loads were applied vertically as it was found by many studies that applying vertical loads on the overdenture generate more stresses than do oblique forces[23].

There was slight difference but with non-statistical significance between the stress values at the peri implant tissue recorded for group A (two implants) and the stress values recorded for the anterior abutments of group B at the different cantilever bar lengths, this non statistical difference can be attributed to the use of bar splinting design between the implants which allow favorable stress distribution between the implants even with use of two or four implant design.

This optimum force distribution around splinted implants allowing bone loading within physiologic limits was reported by many others [44].
Conversaly, others preferred to use two independent implant treatment because of the more costly of the complex treatment involving additional implants and bars splinting inspite of similar treatment outcomes [45]

Zarb and Schmitt[15] and Visser et al[16] indicated that successful implant overdenture treatment outcome can be achieved regardless of the number of implants used,.and therefore Two implants have been consideredthe minimum necessary for mandibular IOD treatment $[1,15]$.

Also, survival rates in the two-implants overdenture groups compared with four-implant overdenture groups appear to be equivalent for patient satisfaction [23].

One ten-year trial displays no significant clinical and radiographic differences in patients treated with two or four implants overdenture [24]. However, a mandibular overdenture with two implants and a bar has fewer complications [25] and this finding supports our result of the favorable results of using two implants with bar splinting specially with distal cantilever bar.

When using two implants, the $11 \mathrm{~mm}$ cantilever bar length generated the highest stress values on the supporting structures whereas the $7 \mathrm{~mm}$ cantilever generated the lowest values and the same finding was found when using four implants. The greater stress values recorded with the the longer cantilever length can be explained by Mericske-Stern et al [30]. Who recommended 5-7 mm distal cantilevered bar lengths on 2 implants supporting a mandibular overdenture. They added that their total lengths must be shorter than the central bar segment and they must not be extended beyond the distal part of the first premolar.

Also, In a photoelastic study, Sadowsky and Caputo[31] established $7 \mathrm{~mm}$ cantilever bar lengths from the distal aspect of 2 implants supporting a mandibular overdenture to accommodate the length of a clip attachment and to minimize the transfer of forces to the implant supporting structure.

\section{Conclusion}

Strain values in the periimplant tissues showed no significant difference when using either two or four implants with the different cantilever bar lengths.

- While when using two implants :The $11 \mathrm{~mm}$ cantilever length generated the highest peri-implant strain values, while the $7 \mathrm{~mm}$ cantilever length recorded the lowest under central loading conditions.

- Also when using four implants the same conclusion was found therefore, a positive correlation between the cantilever length and the peri-implant strain was found.

- Generally, strain reaching the distal supporting structures showed high values in case of using four implants when compared to two implants with the different cantilevered bar lengths. While, when using two implants :The $11 \mathrm{~mm}$ cantilever length generated the highest strain values on the supporting structures, while the $7 \mathrm{~mm}$ cantilever length recorded the lowest under central loading conditions. 


\section{International Journal of Science and Research (IJSR) \\ ISSN (Online): 2319-7064}

Index Copernicus Value (2013): 6.14 | Impact Factor (2014): 5.611

- And when using four implants :the $9 \mathrm{~mm}$ cantilever length generated the highest strain values on the supporting structures, while the $7 \mathrm{~mm}$ cantilever length recorded the lowest under central loading conditions.

- Therefore, it is recommended to use two splinted implant supported over denture with distal cantilever bar of $7 \mathrm{~mm}$ length.

\section{References}

[1] Burns DR, Unger JW, Elswick RK Jr, BeckDA. Prospective clinical evaluation ofmandibular implant overdentures. Part I:retention, stability and tissue response. JProsthet Dent 1995;73:354-63.

[2] Burns DR, Unger JW, Elswick RK Jr, GiglioJA. Prospective clinical evaluation of mandibularimplant overdentures. Part II: patientsatisfaction and preference. J ProsthetDent 1995;73:364-9.

[3] Melas F, Marcenes W, Wright PS. Oralhealth impact on daily performance in patientswith implant-stabilized overdenturesand patients with conventional completedentures. Int J Oral Maxillofac Implants2001;16:700-12.

[4] Thomason JM, Lund JP, Chehade A, FeineJS. Patient satisfaction with mandibularimplant overdentures and conventionaldentures 6 months after delivery. Int JProsthodont 2003;16:467-73.

[5] Awad MA, Lund JP, Shapiro SH, Locker D,Klemetti E, Chehade A, et al. Oral healthstatus and treatment satisfaction with mandibularimplant overdentures and conventionaldentures: a randomized clinical trialin a senior population. Int J Prosthodont2003;16:390-6.

[6] Bakke M, Holm B, Gotfredsen K. Masticatoryfunction and patient satisfaction withimplant-supported mandibular overdentures:a prospective 5-year study. Int JProsthodont 2002;15:575-81.

[7] Doundoulakis JH, Eckert SE, LindquistCC, Jeffcoat MK. The implant-supportedoverdenture as an alternative to the completemandibular denture. J Am Dent Assoc2003;134:1455-8.

[8] Heydecke G, Thomason JM, Awad MA,Lund JP, Feine JS. Do mandibular implantoverdentures and conventional completedentures meet the expectations ofedentulous patients? Quintessence Int2008;39:803-9.

[9] Van der Bilt A, van Kampen FM, Cune MS.Masticatory function with mandibularimplant-supported overdentures fitted withdifferent attachment types. Eur J Oral Sci2006;114:191-6.

[10] Redford M, Drury TF, Kingman A, BrownLJ. Denture use and the technical qualityof dental prostheses among persons 18-74years of age: United States, 1988-1991. JDent Res 1996;75:714-25.

[11] Feine JS, Carlsson GE, Awad MA, ChehadeA, Duncan WJ, Gizani S, et al. The McGillconsensus statement on overdentures.Mandibular two-implant overdentures asfirst choice standard of care for edentulouspatients. Montreal, Quebec, May 24-25, 2002. Int J Oral Maxillofac Implants2002;17:601-2.

[12] Thomason JM, Feine J, Exley C, MoynihanP, Muller F, Naert I, et al. Mandibular twoimplant-supported overdentures as thefirst choice standard of care for edentulouspatients-the York Consensus Statement. BrDent J 2009;207:185-6.
[13] Naert I, Quirynen M, Theuniers G, vanSteenberghe D. Prosthetic aspects of osseointegratedfixtures supporting overdentures.A 4-year report. J Prosthet Dent1991;65:671-80.

[14]Burns DR. Mandibular implant overdenturetreatment: Consensus and controversy. JProsthodont 2000;9:37-46.

[15]Zarb GA, Schmitt A. The longitudinalclinical effectiveness of osseointegrateddental implants: The Toronto study. PartII: The prosthetic results. J Prosthet Dent1990;64:53-61.

[16] Visser A, Raghoebar GM, Meijer HJ, BatenburgRH, Vissink A. Mandibular overdenturessupported by two or four endosseousimplants. A 5-year prospective study. ClinOral Implants Res 2005;16:19-25.

[17] Naert I, Alsaadi G, Quirynen M. Prostheticaspects and patient satisfaction with twoimplant-retained mandibular overdentures:a 10-year randomized clinical study. Int JProsthodont 2004;17:401-10.

[18] Cekic C, Akca K, Cehreli MC. Effects of attachment design on strains around implants supporting overdentures. Quintessence Int. 2007;38:291-297.

[19] Oetterli M, Kiener P, Mericske-Stern R. A longitudinal study on mandibular implants supporting an overdenture: the influence of retention mechanism and anatomic-prosthetic variables on periimplant parameters. Int J Prosthodont. 2001;14:536-542.

[20] Mericske-Stern RD, Taylor TD, Belser U. Management of the edentulous patient. Clin Oral Implants Res. 2000;11:108-125.

[21] Akca K, Akkocaoglu M, Comert A, Tekdemir I, Cehreli MC. Bone strains around immediately loaded implants supporting mandibular overdentures in human cadavers. Int J Oral Maxillofac Implants. 2007;22:101-109.

[22] Mericske-Stern R, Piotti M, Sirtes G. 3-D in vivo force measurements on mandibular implants supporting overdentures. A comparative study. Clin Oral Implants Res. 1996;7:387-396.

[23] Misch CE, Wang HL, Misch CM, Sharawy M, Lemons J, Judy KW. Rationale for the application of immediate load in implant dentistry: part II. Implant Dent. 2004;13:310321.

[24] Lorenzoni M, Pertl C, Zhang K, Wegscheider WA. Inpatient comparison of immediately loaded and non-loaded implants within 6 months. Clin Oral Implants Res. 2003;14:273-279.

[25] Alfadda SA, Attard NJ, David LA. Five-year clinical results of immediately loaded dental implants using mandibular overdentures. Int $\mathrm{J}$ Prosthodont. 2009;22:368-373.

[26] Wismeijer D, Van Waas MA, Vermeeren J,Mulder J, Kalk W. Patient satisfaction withimplant-supported mandibular overdentures.A comparison of three treatmentstrategies with ITI-dental implants. Int JOral Maxillofac Surg 1997:26;263-7.

[27] Duyck J, Van Oosterwyck H, Vander Sloten J, De Cooman M, Puers R, Naert I. In vivo forces on oral implants supporting a mandibular overdenture: the influence of attachment system. Clin Oral Investig. 1999;3:201-207.

[28] Skalak R. Biomechanical considerations in osseointegrated prostheses. J Prosthet Dent $1983 ; 49: 843-848$. 


\section{International Journal of Science and Research (IJSR) \\ ISSN (Online): 2319-7064}

Index Copernicus Value (2013): 6.14 | Impact Factor (2014): 5.611

[29] Jacobs R, Schotte A, van Steenberghe D, Quirynen M, Naert I. Posterior jaw bone resorption in osseointegrated implant-supported overdentures. Clin Oral Implants Res. 1992;3:63-70.

[30] Mericske-Stern R. Force distribution on implants supporting overdentures: the effect of distal bar extensions. A 3-D in vivo study. Clin Oral Implants Res. 1997 Apr;8(2):142-51.

[31] Sadowsky SJ, Caputo AA. Stress transfer of four mandibular implant overdenture cantilever designs. J Prosthet Dent. 2004;92:328-336.

[32] Heckmann SM, Winter W, Meyer M, Weber HP, Wichmann MG. Overdenture attachment selection and the loading of implant and denture-bearing area. Part 2: A methodical study using five types of attachment. Clin Oral Implants Res. 2001;12:640-647.

[33] Tang L, Lund JP, Tache R, Clokie CM, Feine JS. A withinsubject comparison of mandibular long-bar and hybrid implant-supported prostheses: psychometric evaluation and patient preference. J Dent Res. 1997;76:1675-1683.

[34] Krennmair G, Krainhofner M, Piehslinger E. The influence of bar design (round versus milled bar) on prosthodontic maintenance of mandibular overdentures supported by 4 implants: a 5 -year prospective study. Int J Prosthodont. 2008;21:514-520.

[35] Assuncao WG, Barao VA, Tabata LF, Gomes EA, Delben JA, dos Santos PH. Biomechanics studies in dentistry: bioengineering applied in oral implantology. J Craniofac Surg. 2009;20:1173-1177.

[36] Akca K, Cehreli MC, Iplikcioglu H. A comparison of three-dimensional finite element stress analysis with in vitro strain gauge measurements on dental implants. Int J Prosthodont. 2002;15:115-121.

[37] Heckmann SM, Winter W, Meyer M, Weber HP, Wichmann MG. Overdenture attachment selection and the loading of implant and denture-bearing area. Part 1: In vivo verification of stereolithographic model. Clin Oral Implants Res. 2001;12:617-623.

[38] Maeda Y, Horisaka M, Yagi K. Biomechanical rationale for a single implant-retained mandibular overdenture: an in vitro study. Clin Oral Implants Res. 2008;19:271-275.

[39] Misch CE. Treatment Options for Mandibular Implant Overdentures in: Misch CE, Bidez MW, Judy KWM et al, eds Dental implant prosthetics. 3nd ed St Louis: Mosby. 2005: 218-235.

[40] Tokuhisa M, Matsushita Y, Koyano K. In vitro study of a mandibular implant overdenture retained with ball, magnet, or bar attachments: comparison of load transfer and denture stability. Int J Prosthodont. 2003;16:128134.

[41]Darbar UR, Huggett R, Harrison A. Stress analysis techniques in complete dentures. J Dent. 1994;22:259264.

[42] Prombonas AE, Vlissidis DS. Comparison of the midline stress fields in maxillary and mandibular complete dentures: a pilot study. J Prosthet Dent. 2006;95:63-70.

[43] Duyck J, Ronold HJ, Van Oosterwyck H, Naert I, Vander Sloten J, Ellingsen JE. The influence of static and dynamic loading on marginal bone reactions around osseointegrated implants: an animal experimental study. Clin Oral Implants Res. 2001;12:207-218.

\section{Author Profile}

Jailan Ahmed Salem, received the B.D.S. in Dental and Oral Surgery from Alexandria University, faculty of dentistry 2006. During 2006-2007, she practiced in Ministry of Health. Since 2009 till now, she worked as a demonstrator in pharos university. During 20102015 , she educated for M.S degree in prosthodontics in prosthetic department, faculty of dentistry. Alexandria University. 